mitn +5

INSTITUTE OF DEVELOPMENT STUDIES

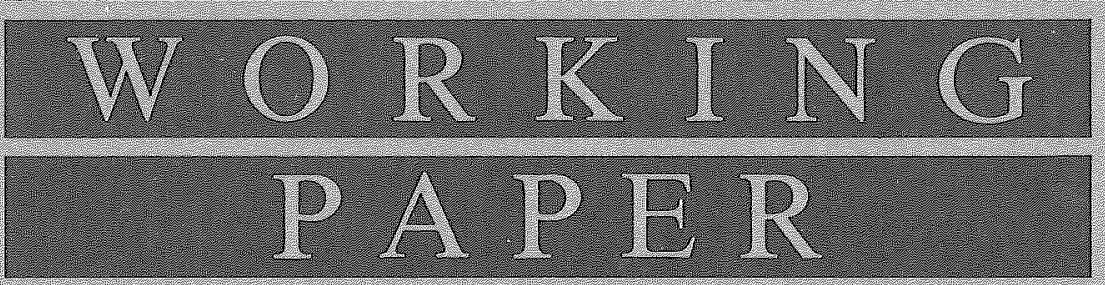

2.

April 1994

Paradigm Shifts and the

Practice of Participatory

Research and Development

ROBERT CHAMBERS

Preliminary material and interim research results circulated to stimulate discussion and critical comment

O INSTITITE OF DEVELOPMENT STUDIES 1994

ISBN 185864 051 2 


\section{Paradigm Shifts and the Practice of Participatory Research and Development}

\section{$\underline{\text { Abstract }}$}

"Participation" has three uses and meanings: cosmetic labelling, to look good; co-opting practice, to secure local action and resources; and empowering process, to enable people to take command and do things themselves. Its new popularity is part of changes in development rhetoric, thinking and practice. These have been shifting from a standardised, top-down paradigm of things towards a diversified, bottom-up paradigm of people. This implies a transfer of power from "uppers" - people, institutions and disciplines which have been dominant, to "lowers" - people, institutions and disciplines which have been subordinate. The many labels and schools of participatory approaches in research and development tend to hide underlying changes in philosophy and practice. Rapid rural appraisal leading to participatory rural appraisal (PRA) is one example of a shift from data collection to data sharing and empowerment. With PRA, poor people have shown far greater capabilities to appraise, analyse, plan and act than professionals have expected. Empowerment of the poor requires reversals and changes of role. Some of the new approaches and methods, especially of PRA, make reversals less difficult and improbable than they used to be. PRA faces many dangers. For it to be used on any scale in an empowering mode implies widespread changes in bureaucratic procedures and cultures, including more participatory management.

\section{A. "Participation"}

The language of development rhetoric and writing changes fast. The reality of development practice lags behind the language. Sometimes the language lapses into history, as with "take-off into self-sustaining growth" which took off into self-negating decline. In other cases words persist and prevail, whatever happens to the field reality. "Participation" is one such word which is experiencing a renaissance in the 1990s. So widespread is its use that some talk of a paradigm shift to participatory development. This chapter examines this view, arguing that reversing power relations is the key, and the weak link, in achieving participation.

Three ways in which "participation" is used stand out. 
First, it is used as a cosmetic label, to make whatever is proposed appear good. Donor agencies and governments require participatory approaches and consultants and managers say that they will be used, and then later that they have been used, while the reality has often been top-down in a traditional style.

Second, it describes a co-opting practice, to mobilise local labour and reduce costs. Communities contribute their time and effort to self-help projects with some outside assistance. Often this means that "they" (local people) participate in "our" project.

Third, it is used to describe an empowering process which enables local people to do their own analysis, to take command, to gain in confidence, and to make their own decisions. In theory, this means that "we" participate in "their" project, not "they" in "ours". It is with this third meaning and use that we are mainly concerned here.

\section{B. The Paradigm Shift, from Things to People}

The new popularity of participation has several origins: recognition that many development failures originate in attempts to impose standard top-down programmes and projects on diverse local realities where they do not fit or meet needs; concern for costeffectiveness, recognising that the more local people do the less capital costs are likely to be; preoccupation with sustainability, and the insight that if local people themselves design and construct they are more likely to meet running costs and undertake maintenance; and ideologically for some development professionals, the belief that it is right that poor people should be empowered and should have more command over their lives.

The new stress on participation can also be understood in terms of a deeper and more pervasive shift in development thinking. In development, paradigm shifts differ from those in the physical sciences. "Paradigm" is used here to mean a pattern of ideas, values, methods and behaviour which fit together and are mutually reinforcing. In the physical sciences, one new paradigm tends to replace an old one. In development thinking, paradigms tend to coexist, overlap, coalesce and separate. As Norman Uphoff has argued (1992) thinking in development needs to be "both-and" rather than "either-or". However, to illuminate major trends it can still help to set out polarised extremes. Arguably, the big shift of the past two decades has been from a professional paradigm centred on things to one centred on people. 
Table 1: Two Paradigms: Things and People

\begin{tabular}{|c|c|c|}
\hline $\begin{array}{l}\text { Point of departure and } \\
\text { reference }\end{array}$ & Things & People \\
\hline Mode & Blueprint & Process \\
\hline Keyword & Planning & Participation \\
\hline Goals & Pre-set, closed & Evolving, open \\
\hline Decision-making & Centralised & Decentralised \\
\hline Analytical assumptions & Reductionist & Systems, holistic \\
\hline $\begin{array}{l}\text { Methods, } \\
\text { Rules }\end{array}$ & Standardised & Diverse \\
\hline Technology & $\begin{array}{l}\text { Universal } \\
\text { Fixed package } \\
\text { (table d'hôte) }\end{array}$ & $\begin{array}{l}\text { Local } \\
\text { Varied basket } \\
\text { (à la carte) }\end{array}$ \\
\hline $\begin{array}{l}\text { Professionals' interactions } \\
\text { with clients }\end{array}$ & Motivating & Enabling \\
\hline Clients seen as & $\begin{array}{l}\text { Controlling } \\
\text { Beneficiaries }\end{array}$ & $\begin{array}{l}\text { Empowering } \\
\text { Actors, partners }\end{array}$ \\
\hline Force flow & Supply-push & Demand-pull \\
\hline Outputs & Uniform & Diverse \\
\hline & Infrastructure & Capabilities \\
\hline Planning and Action & Top-down & Bottom-up \\
\hline
\end{tabular}

The paradigm of things was dominant in development in the 1950s and 1960s, with emphasis placed on big infrastructure, industrialisation and irrigation works. Economists and engineers, and their top-down physical and mathematical paradigm, determined norms, procedures and styles. Economic analysis continues in the 1990 s to be the dominant mode of development thinking and practice, but the paradigm of people has come to be increasingly influential. This is shown by the burgeoning literature on people and participation (eg Cernea 1985, 1991; Uphoff 1992; Burkey 1993), by the increase in numbers of non-economist social scientists in some aid agencies, notably ODA, and by the 
development and spread of participatory approaches and methods. Social anthropologists and NGOs in particular have shifted the balance from things to people. The rhetoric of development now widely favours putting people first, and often, putting poor people first of all.

In theory, the shift from the paradigm of things to the paradigm of people entails much change. Top-down becomes more bottom-up. The uniform becomes diverse, the simple complex, the static dynamic, and the controllable uncontrollable. The future becomes less predictable. The transfer of packages of technology is replaced by the presentation of baskets of choice. Most difficult, the paradigm of people implies the third meaning or use of participation, to describe empowering process, with a shift of power to those who are local and poor.

In practice, the top-down reality has, though, changed rather little. Many reasons can be adduced to explain this. The paradigm of things remains strong, not least because it is needed for dealing with things: bridges are needed which are strong, safe and durable.

Other reasons include:

* normal professionalism - the concepts, values, methods and behaviour dominant in professions - which seeks and values controlled conditions and universal truths (Chambers 1993 chapters 1 and 6)

* normal bureaucracy - the concepts, values, procedures and behaviour dominant in bureaucracies, with their tendencies to centralise, standardise and control

* normal (successful) careers in which promotion separates power from field realities

* normal teaching which reproduces normal professionalism, transferring knowledge from the teacher who knows, to the pupil who is ignorant.

Normal professionalism, bureaucracy, careers and teaching combine in top-down standardisation and pressures for speedy action. Most importantly there is power. Participation as empowering process implies loss of central control and proliferation of local diversity. The powerful are threatened with loss of power. 


\section{Power Relations: Uppers and Lowers}

Human society, in this context, can be thought of as patterned into hierarchical relationships, by analogy described as North and South. Many relationships are vertical, between "uppers". and "lowers".

Table 2: North-South, Upper-Lower Relationships

\begin{tabular}{|c|c|c|}
\hline Dimension/context & $\begin{array}{l}\text { North } \\
\text { Uppers }\end{array}$ & $\begin{array}{l}\text { South } \\
\text { Lowers }\end{array}$ \\
\hline Spatial & Core (urban, industrial) & $\begin{array}{l}\text { Periphery (rural, } \\
\text { agricultural) }\end{array}$ \\
\hline $\begin{array}{l}\text { International and } \\
\text { development }\end{array}$ & $\begin{array}{l}\text { The North } \\
\text { IMF, World Bank } \\
\text { Donors } \\
\text { Creditors } \\
\end{array}$ & $\begin{array}{l}\text { The South } \\
\text { Poor countries } \\
\text { Recipients } \\
\text { Debtors }\end{array}$ \\
\hline Personal ascriptive & $\begin{array}{l}\text { Male } \\
\text { White } \\
\text { High ethnic or caste group }\end{array}$ & $\begin{array}{l}\text { Female } \\
\text { Black } \\
\text { Low ethnic or caste group }\end{array}$ \\
\hline Life cycle & $\begin{array}{l}\text { Old person } \\
\text { Parent } \\
\text { Mother-in-law }\end{array}$ & $\begin{array}{l}\text { Young person } \\
\text { Child } \\
\text { Daughter-in-law }\end{array}$ \\
\hline Bureaucratic organisation & $\begin{array}{l}\text { Senior } \\
\text { Manager } \\
\text { Official } \\
\text { Patron } \\
\text { Officer } \\
\text { Warden, guard } \\
\end{array}$ & $\begin{array}{l}\text { Junior } \\
\text { Worker } \\
\text { Supplicant } \\
\text { Client } \\
\text { "other rank" } \\
\text { Inmate, prisoner }\end{array}$ \\
\hline Social, spiritual & $\begin{array}{l}\text { Patron } \\
\text { Priest } \\
\text { Guru } \\
\text { Doctor, psychiatrist }\end{array}$ & $\begin{array}{l}\text { Client } \\
\text { Lay person } \\
\text { Disciple } \\
\text { Patient }\end{array}$ \\
\hline Teaching and learning & $\begin{array}{l}\text { Master } \\
\text { Lecturer } \\
\text { Teacher }\end{array}$ & $\begin{array}{l}\text { Apprentice } \\
\text { Student } \\
\text { Pupil }\end{array}$ \\
\hline
\end{tabular}

Individuals are multiple uppers or multiple lowers, and a person can be an upper in one context and a lower in another. 


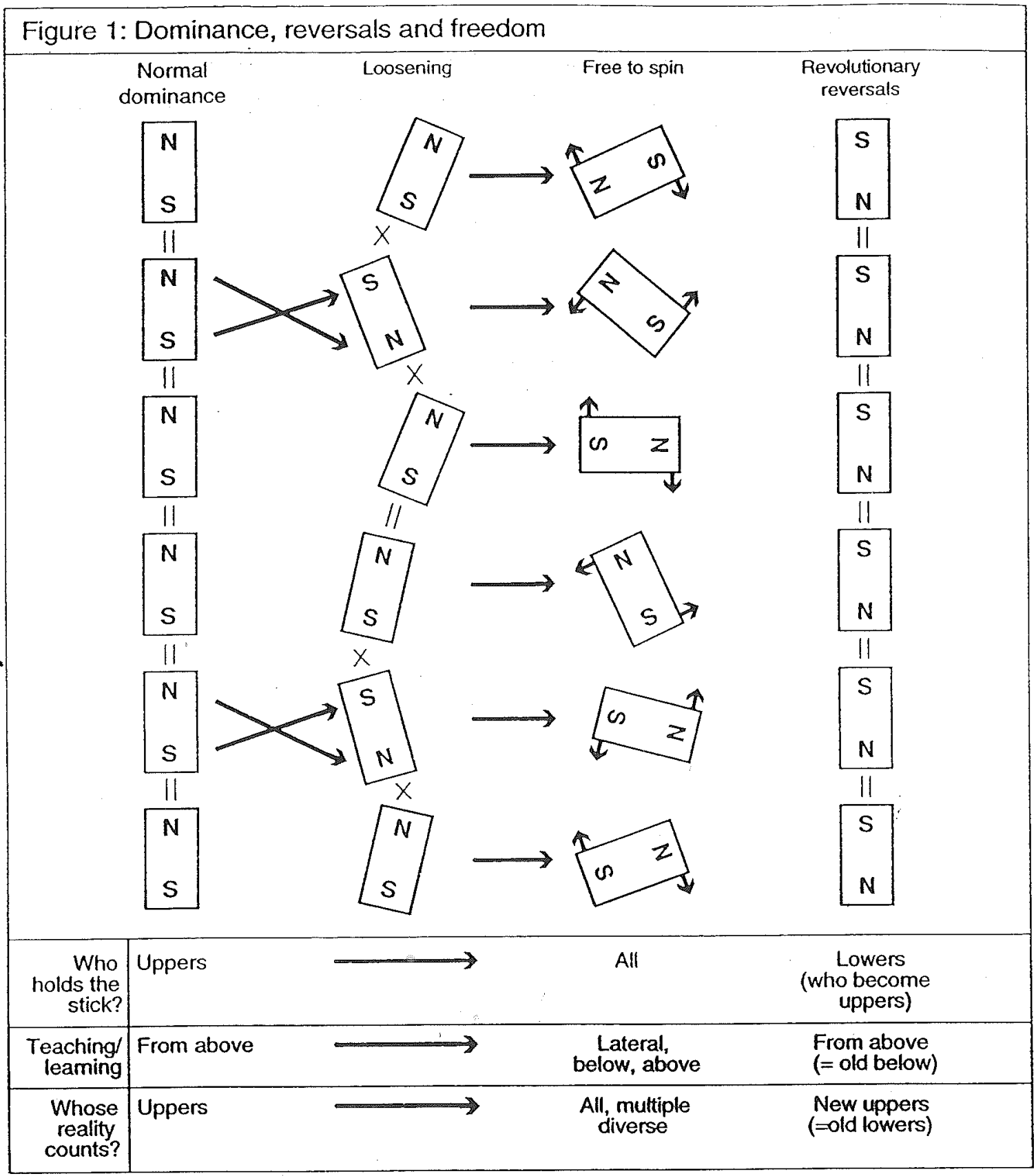


$\mathrm{N}-\mathrm{S}$, upper-lower, patterns can be thought of as a magnetic field, where the magnets are mutually reinforcing in orientation. In the normal strong N-S field, if lowers participate, it is in activities determined by uppers. If there is a revolutionary flip, lowers become uppers, and a similar situation is reproduced, as in the USSR under Stalin and China under Mao. Participation which empowers requires a weakening of the magnetic field at various levels, with scope for lateral linkages with peers, colleagues, neighbours, and fellow citizens.

The roles of dominant uppers have then to change. From planning, issuing orders, transferring technology, and supervising, they shift to convening, facilitating, searching for what people need, and supporting. From being teachers they become facilitators of learning. They seek out the poorer and weaker, bring them together, and enable them to conduct their own appraisal and analysis, and take their own action. The dominant uppers "hand over the stick", sit down, listen and themselves learn.

\section{Change and Spread}

The extent to which this has already happened is difficult to judge. While the top-down paradigm of things remains dominant, many changes have occurred and together have a momentum towards the paradigm of people. Perhaps the most notable has been a proliferation of schools and methods for participatory approaches. Twenty-nine which have developed since the 1970s have been identified (table 3 ) and others could be added.

These new approaches and labels reflect deep and widespread shifts of emphasis and changes in methods and behaviour, especially but not only in NGOs; and with or without adopting approaches such as these, many organisations have sought to move towards less authoritarian and centralised styles of management. Three families of approaches illustrate the more widespread changes.

First, a huge literature now testifies to the greater participation of farmers in agricultural research and extension (see Amanor 1989 for an annotated bibliography; also Farrington and Martin 1988; Chambers, Pacey and Thrupp 1989; ILEIA 1985-; Farrington and Bebbington 1993; Scoones and Thompson (eds) forthcoming). Farming systems research in its classical style made a huge contribution to professional understanding, based on outsiders' data collection and analysis. The overlapping approaches of farmer 
participatory research, participatory technology development, and farmer-first approaches in contrast involve farmers more in the identification of priorities, in the design, conduct and analysis of experiments, and in monitoring and evaluation.

Table 3: Some participatory approaches which have developed since the 1970s (in alpabetical order)

\begin{tabular}{|ll|}
\hline AEA & Agroecosystem Analysis \\
BA & Beneficiary Assessment \\
DELTA & Development Education Leadership Teams \\
D\&D & Diagnosis and Design \\
DRP & Diagnostico Rural Participativo \\
FPR & Farmer Participatory Research \\
FSR & Farming Systems Research \\
GRAAP & Groupe de recherche et d'appui pour l'auto-promotion paysanne \\
MARP & Méthode Accéléré de Recherche Participative \\
PALM & Participatory Analysis and Learning Methods \\
PAR & Participatory Action Research \\
PD & Process Documentation \\
PRA & Participatory Rural Appraisal \\
PRAP & Participatory Rural Appraisal and Planning \\
PRM & Participatory Research Methods \\
PTD & Participatory Technology Development \\
RA & Rapid Appraisal \\
RAAKS & Rapid Assessment of Agricultural Knowledge Systems \\
RAP & Rapid Assessment Procedures \\
RAT & Rapid Assessment Techniques \\
RCA & Rapid Catchment Analysis \\
REA & Rapid Ethnographic Assessment \\
RFSA & Rapid Food Security Assessment \\
RMA & Rapid Multi-perpective Appraisal \\
ROA & Rapid Organisational Assessment \\
RRA & Rapid Rural Appraisal \\
SB & Samuhik Brahman (Joint Trek) \\
TFD & Theatre for Development \\
TFT & Training for Transformation \\
\hline
\end{tabular}

Source: Cornwall, Guijt and Welbourn 1993:14 
Second, much work has been done in developing approaches to the participatory management of local natural resources. This includes joint forest management in India (Poffenberger et al $1992 \mathrm{a}$ and $\mathrm{b}$ ) and elsewhere, where forests are managed jointly by local people and by Government Forest Departments; irrigation management (Bagadion and Korten 1991; Uphoff 1992) where small systems are managed and maintained by communities, and lower parts of larger systems are turned over to groups of irrigators to manage; and watershed management where farmers plan, act, monitor and evaluate measures for soil and water conservation on their fields (Fernandez 1993; Shah 1993).

Third, several streams of approaches and methods - applied social anthropology (eg Rhoades 1982), agroecosystem analysis (Conway 1985), farming systems research (Gilbert et al 1980; Shaner et al 1982, FSSP 1987), participatory research (much of it flowing from the work of Paulo Freire) and rapid rural appraisal (Agricultural Administration 1981, Longhurst 1981; KKU 1987) - while continuing as useful practices, have also intermingled in a lively confluence of innovation bearing various labels, including participatory rural appraisal (PRA) (Mascarenhas et al 1991; Chambers 1992b). Rapid rural appraisal leading to participatory rural appraisal is one example of shift from outsiders' data-collection to local empowerment as the dominant mode. The view is strongly held among leading PRA practitioners that processes should only be described as "PRAs" if they are empowering, especially for those who are poor, weak and vulnerable.

These three families of approaches have spread rapidly among NGOs, and are now, in the mid-1990s, spreading significantly in some large government organisations. These are little researched and not well documented, so that it is difficult to assess the scale and depth of change. There is a danger of misleading positive feedback (Chambers 1992a; 1994) including special cases. Nevertheless, there are sufficient examples of government organisations concerned with agriculture, forestry, irrigation, and soil and water conservation, especially in Asia and Sub-Saharan Africa, to suggest that despite setbacks slow shifts towards greater participation are occurring on a wide scale.

\section{E. The Paradigm Shift in Practice}

The shift towards empowering participation has been helped by new practices. Four stand out: 


\section{i. enabling and "they can do it"}

Again and again it has been found that activities it was supposed outsiders had to perform can be performed as well or better by insiders - local people, and whether literate or nonliterate, when the outsiders encourage them and give them confidence that "they can do it". These activities include appraisal, analysis, planning, experimenting, implementing, and monitoring and evaluation. Beyond this, local people are good extensionists, and facilitators for each others' analysis. (A village volunteer has sent a note to an Aga Khan Rural Support Programme staff member in Gujarat saying - we are going to conduct a PRA - you do not need to come). Villagers have also presented their analyses in capital cities (with PRA in Colombo, Dhaka and Gaborone). They have also begun to become trainers for NGO staff.

\section{ii. lateral spread by peers}

Increasingly, technologies, approaches and methods are spread laterally by peers rather than vertically through transfer of technology. Farmer-to-farmer extension, both within and between countries and ecological zones, is becoming more prevalent. In PRA, the best trainer/facilitators for other villages and other villagers are local people who have already gained experience. (The best teachers of students are also often other students, a lesson which hierarchically organised universities might do well to note and act on.)

\section{iii. group-visual synergy}

Group-visual synergy refers to what often happens when a group of people engage in a visual form of analysis. Examples are mapping, scoring with seeds or counters, and making diagrams of changes, trends and linkages. As groups cumulatively build up a visual representation of their knowledge, judgements and preferences, they tend to increase in commitment and enthusiasm, and to generate consensus. The role of the outsider is to convene, initiate and facilitate such a group process. It is the insiders who are the analysts.

The outsiders observe, and can see and judge the validity of what is being shown and shared. There are opportunities to encourage and support weaker and shyer members of a community, either to join in with a group, or to form their own. Often both the outsiders and the analysts find the process interesting, and often fun. 


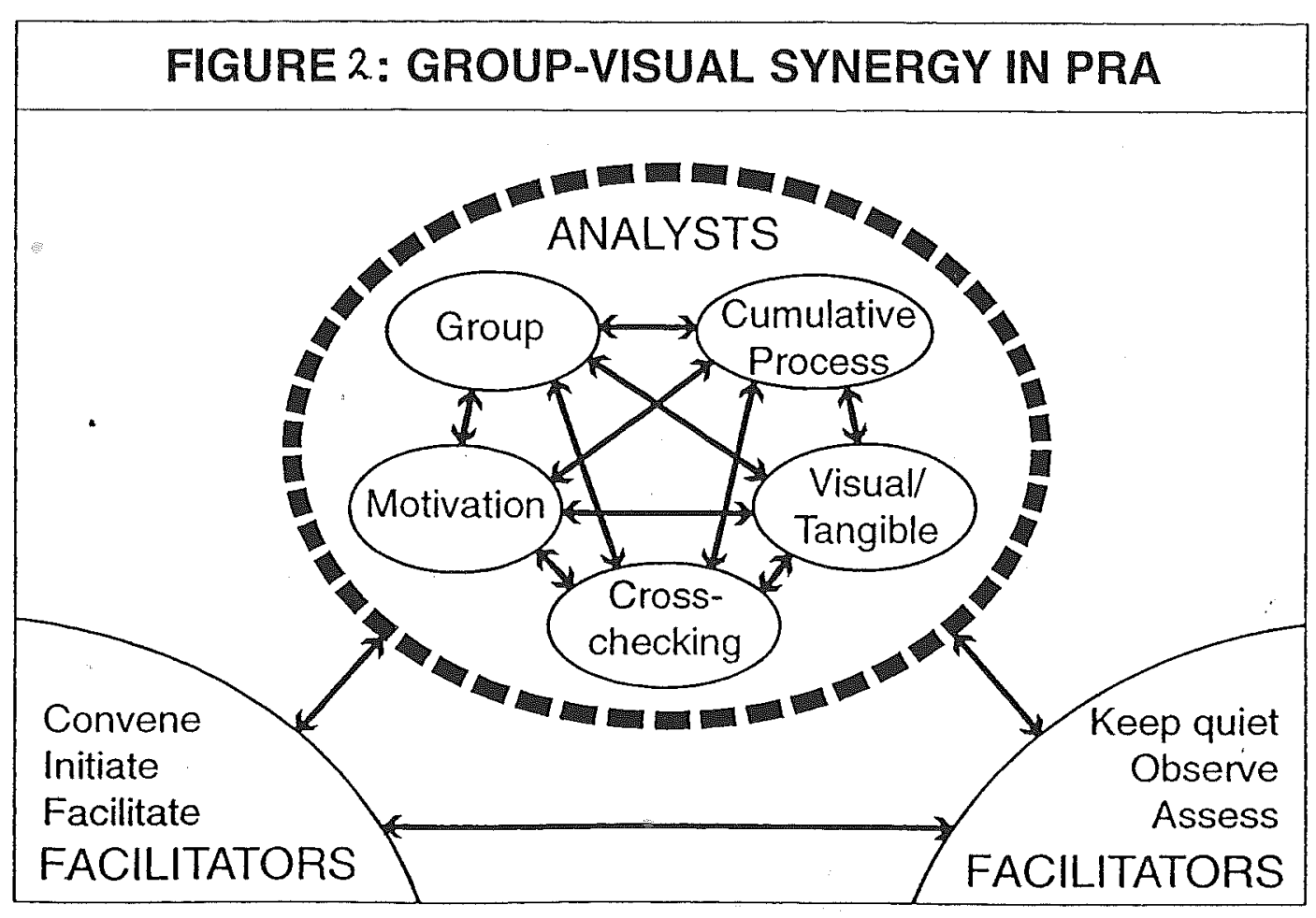


iv. behaviour and attitude training for uppers

A key element usually missing from earlier participatory efforts is the behaviour and attitudes of outsiders. Empowerment of the poor requires reversals and changes of role. In PRA this has come to be recognised as more important than the methods. In consequence, much PRA training stresses how uppers behave with lowers, and handing over the stick, sitting down, listening and learning, facilitating, not wagging the finger or lecturing, and being respectful and considerate. With hindsight, it is astounding that this has not been regarded as fundamental in development work, and that it is only in the 1990s that it is coming to the fore. Some of the new approaches and methods, especially of PRA, make reversals less difficult and improbable than they used to be because they are found to be both effective, interesting and fun.

\section{F. Traps and Problems in Participation}

- PRA and other participatory approaches face many traps and problems. No listing is likely to be complete, but some of the more obvious and important are the following:

* who participates? Missing the poorer. A pervasive problem is upper-to-upper biases, interacting with the local elite and with men, and missing the poorer and women. Finding and involving those who are normally left out, and what has been termed "the analysis of difference" (Welbourn 1991) will always be challenges. Nor is it enough to identify just one category, such as women. For there are poor and less poor women, and many other differences between groups and categories of people. The poorest, who live far from the centre, who are weak, or overworked, or used to being excluded, are easily left out of empowering participatory processes.

* rushing. Facilitators are often in a hurry. Whether they are foreign visitors, government officials, or NGO staff, unless they stay in villages their visits are constrained by time, and rushing often means leaving out the peripheral and the poorest, being misled by the less poor, and failing to facilitate an on-going process.

* self-sustaining myth. Power relations lead can to mutual deception by uppers and lowers, by visitors and villagers. Inadvertent ventriloquism occurs when uppers are told what lowers think they want to hear. Myths presented by villagers for reasons of 
hope of gain, fear of penalty, or self-respect and self-identity, can be accepted and disseminated by outsiders as the reality. Visual diagramming methods often diminish distortions, but even with visualisation, the public nature of the event can generate misinformation (Mosse 1993). All power deceives (Chambers 1994). PRA and PRA methods well applied reduce but may not eliminate the distorting effects of power relations.

* routine and ruts. Stepwise manuals appeal to teachers and students alike, providing secure rules for right behaviour. Participation which truly empowers implies process which is unpredictable. So the more that rigid rules and sequences are followed, the lower the level of participation is likely to be. The best PRA manual has one sentence on the first page "Use Your Own Best Judgement At All Times", and all the remaining pages are blank (KGVK c. 1990).

* cosmetics: label without substance. The greatest danger with participation is that the words will be used without the reality of changed behaviour, approaches and methods.

- The key remains behaviour. Unless the behaviour of most outsiders changes, participation will not be more than partial.

\section{G. Implications}

The implications of the paradigm of people are many. For it to be used on any scale in an empowering mode implies widespread changes in bureaucratic procedures and cultures, including participatory management. Upper-lower relationships of authority will always be needed, so the shift required is relative, not absolute. It affects almost all human relationships, between uppers and lowers, and between peers. Any agenda might include:

* changing the culture and procedures of development organisations (multilateral and bilateral donors, government departments in headquarters and the field, NGOs, research institutes, training centres, universities and colleges...) towards participatory management, decentralisation, and priority to the front-line workers.

* projects concerned with people to be processes of learning, enabling and empowering, with open-ended time frames allowing for participation and change, while blueprint approaches with rigid time frames and set targets to be confined to things, limited to some physical aspects of infrastructure. 
* changing to a more participatory and open-ended social science research, with more of the agenda, appraisal and analysis by local people, and the outcomes owned and shared by them. This implies also changes in relationships between funding bodies and researchers, and between supervisors and those conducting research for theses.

* determination of priorities in agricultural, forestry, fisheries and other natural resource research much more by and through the analysis and experience of local people, weighted to give voice to women, the weak and the poor

* changing approaches and methods in teaching and training away from the lecture mode to shared learning, peer instruction, problem solving, and social settings in which the shy and retiring feel able to contribute, and in which all teaching and training includes experiential learning concerning upper-lower behaviour and attitudes

All this means that the new challenges for the 21 st century face the rich and powerful

- more than the poor and weak, for they concern reversals, giving things up. For the rich to give up their wealth, without being forced by countervailing power, is difficult and improbable; but for uppers to give up dominance at the personal level, putting respect in place of superiority, becoming a convenor, and provider of occasions, a facilitator and catalyst, a consultant and supporter, is less difficult; for these roles bring with them many satisfactions and non-material rewards. Perhaps one of the biggest opportunities now is to enable more and more uppers to experience those satisfactions personally, and then themselves to spread them, upwards, downwards, and laterally to their peers. For participation, in the full empowering sense of reversals, is not for one place or one set of people, but is itself a paradigm - a pattern of ideas, values, methods and behaviour - which can apply to almost all social activity and spread in all directions.

March 1994

Robert Chambers

Institute of Development Studies

University of Sussex

Brightin BN1 9RE 
Acknowledgements

For comments on a draft for this paper I am grateful to Sue Wright and for ideas about uppers and lowers to Jenny Chambers.

This paper is forthcoming in: Nici Nelson and Susan Wright (eds.), Power and

Participatory Development, Intermediate Technology Publications, September 1994, price L5.95. 


\section{References}

Agricultural Administration, 1981, Vol 8 No 6, Special Issue on Rapid Rural Appraisal

Amanor, K., 1989, "Abstracts on Farmer Participatory Research", Agricultural

Administration (R\&E) Network Paper No 5, London: ODI

Bagadion, B.U. and Korten, F.F., 1991, "Developing Irrigators' Organizations; a Learning Process Approach", in: M.M. Cernea (ed.) Putting People First, Oxford: Oxford University Press, 2nd Edition

Burkey, S., 1993, People First: a Guide to Self-reliant Participatory Rural Development, Zed Books Ltd

Chambers, R., 1992a, "The Self-deceiving State", IDS Bulletin, Vol 23 No 4: 31-42

- Chambers, R., 1992b, "Rural Appraisal: Rapid, Relaxed and Participatory", Discussion Paper No 311, Brighton: IDS

Chambers, R., 1993, Challenging the Professions: Frontiers for Rural Development, London: Intermediate Technology Publications

Chambers, R., 1994, "All Power Deceives", IDS Bulletin, Brighton: IDS

Chambers, R., Pacey, A., and Thrupp, L., 1989, Farmer First: farmer innovation and agricultural research, London: Intermediate Technology Publications

Cernea, Michael, (ed.), 1991, Putting People First: Sociological Variables in Rural Development (second edition, first edition 1985), Oxford University Press for the World Bank

Conway, G., 1985, "Agroecosystem Analysis", Agricultural Administration 20: 31-55

Cornwall, A., Guijt, I., and Welbourn, A., 1993, "Acknowledging Process: Challenges for Agricultural Research and Extension Methodology", Discussion Paper No 333, Brighton: IDS 
Farrington, J., and Martin, A., 1988, "Farmer Participation in Agricultural Research: A Review of Concepts and Practices", Agricultural Administration Occasional Paper No 9, London: Overseas Development Institute

Farrington, J., and Bebbington, A. with Wellard, K. and Lewis, D.J., 1993, Reluctant Partners? Non-Governmental Organizations, the State and Sustainable Agricultural Development, London and New York: Routledge

Fernandez, A.P., 1993, The MYRADA Experience: the Interventions of a Voluntary Agency in the Emergence and Growth of People's Institutions for Sustained and Equitable Management of Micro-Watersheds, MYRADA, No 2 Service Road, Domlur Layout, Bangalore 560 071, India, July

FSSP, 1987, Diagnosis, Design and Analysis in Farming Systems Research and Extension, Volumes I, II and III, and Trainer's Manual, Farming Systems Support Project, Institute of Food and Agricultural Sciences, University of Florida, Gainesville, Florida 32611, December

Gilbert, E.H., W. Norman and F.E. Winch, 1980, "Farming Systems Research: A Critical Appraisal", MSU Rural Development Paper No 6, Department of Agricultural Economics, Michigan State University, East Lansing, Michigan 48824

ILEIA, 1985 - present, ILEIA Newsletter, Information Centre for Low External Input and Sustainable Agriculture, Leusden, Netherlands

KKU, 1987, Proceedings of the 1985 International Conference on Rapid Rural Appraisal, Rural Systems Research and Farming Systems Research Projects, University of Khon Kaen, Thailand

KGVK, 1991, Management Training Manual, Krishi Gram Vikas Kendra, Ranchi, Bihar, India

Longhurst, R. (ed.), 1981, Rapid Rural Appraisal, IDS Bulletin, Vol 12 No 4 
Mascarenhas, J. et al, 1991, Participatory Rural Appraisal: Proceedings of the February 1991 Bangalore PRA Trainers' Workshop, RRA Notes 13, IIED, London and MYRADA, Bangalore

Mosse, D., 1993, "Authority, Gender and Knowledge: theoretical reflections on the practice of participatory rural appraisal", Agricultural Administration (Research and Extension) Network Paper No 44, London: Overseas Development Institute

Poffenberger, M., B. McGean, N.H. Ravindarnath and M. Gadgil (eds.), 1992a, Joint Forest Management Field Methods Manual Volume 1 Diagnostic Tools for Supporting Joint Forest Management Systems, Society for the Promotion of Wastelands Development, 1 Copernicus Marg, New Delhi 110001

Poffenberger, M., B. McGean, A. Khare and J. Campbell (eds.), 1992b, Joint Forest Management Field Methods Manual Volume 2 Community Forest Economy and Use Patterns: Participatory Rural Appraisal (PRA) Methods in South Gujarat, - India, Society for the Promotion of Wastelands Development, 1 Copernicus Marg, New Delhi 110001

Rhoades, R., 1982, The Art of the Informal Agricultural Survey, International Potato Center, Apartado 5969, Lima

Scoones, I. and Thompson, J. (eds.), forthcoming, Beyond Farmer First: Rural People's Knowledge, Agricultural Research and Extension Practice, London: Intermediate Technology Publications

Shah, P., 1993, "Participatory Watershed Management Programmes in India: Reversing Our Roles and Revising Our Theories", in Rural People's Knowledge, Agricultural Research and Extension Practice, IIED Research Series Vol 1 No 3: 38-67 London: IIED

Shaner, W.W., P.F. Philipp and W.R. Schmehl, 1982, Farming Systems Research and Development: Guidelines for Developing Countries, Westview Press, Boulder, Colorado 
Uphoff, N., 1992, Learning from Gal Oya: Possibilities for Participatory Development and Post-Newtonian Social Science, Cornell University Press

Welbourn, A., 1991 "RRA and the Analysis of Difference", RRA Notes 14: 14-23, London: IIED

RChm PARAPAN.DOC 6.4.94 